\title{
PREVALENCE OF BEAK AND SHANK NECROSIS IN CROSS-BRED CHICKENS
}

\author{
Moshira A. El-Abasy";Amal E. Youssef" and A. A El-Gohary". \\ "Dept. of Poultry Diseases, Faculty of Vet. Med., Kafr El-Sheikh University. \\ Animal Health Research Institute, Dokki.
}

\begin{abstract}
The anaerobic, Gram negative, filamentous bacteria associated with severe beak and shank necrosis in chickens was identified as Fusobacterium necrophorum (F. necrophorum). Bacteriological isolation from affected beak, liver and shank revealed a single morphological type of Gram negative, filamentous bacterium within the dermis of the affected beak and shank of the fowl. A hemagglutination test for identification of $F$. necrophorum was described. The antibiogram of the isolated strains was investigated. Beak and shank necrosis occur in 56\% of chickens. The mortality was 2-13\%. Characterestic gross lesions of affected chickens were swelling and necrosis of the beak, curvature of the upper mandible with necrosis of the lower mandible and shanks. Histopathologically, there were hyperkeratosis and keratolysis in epidermis of the beak with infiltration of rod-shaped microorganisms in dermal regions suffered from coagulative necrosis. The epidermis of the affected shanks showed hyperkeratosis, hyperplastic changes and coagulative necrosis of the underlying tissue intangled with bacteria.
\end{abstract}

\section{INTRODUCTION}

Avian necrobacillosis is a cutaneous disease affecting head and legs of chickens caused by Fusobacterium necrophorum (F. necrophorum) alone or in combination with other pathogen. F.necrophorum initiates 
infection in birds by attacking the dermis of the head and legs causing necrotic ulcerations with hypertrophy of the upper or lower beak or sometimes both with erosions and necrosis of the beak and shanks of the affected flock (Cheng et al. 1976). Necrosis of the tip of the tongue was always a complication (Barr, 1965). Focal cutaneous necrosis is seen as a lesion of systemic cutaneous lesions in avian pox (Tripathy, 1991) and fungal infections (Hungerford, 1969). Anaemia, congestion and atrophy of the beak and shank are seen as non specific lesions. No publications recording avian necrobacillosis in Egypt are available. This paper aimed to identify the cause of out break of beak and shank necrosis in broiler chickens.

\section{MATERIALS AND METHODS}

One hundred and eleven cross-bred broiler chickens (5-7-week-old) from Gharbia Province(Table 1)were subjected to clinical and postmortem examinations. The chickens were raised on floors. The flocks received vaccine for Marek's disease at 0-day-old and mixed live vaccine for Newcastle and infectious bronchitis via drinking water at 14 and 21 days of age.

\section{Specimens:}

Swabs from the affected beaks, tongues and legs and loopfuls from livers were taken for bacterial isolation (Cheng et al. 1976).

\section{Media and reagents:}

Solid media: MacConkey's agar, brain heart infusion (BHI) agar, Tryptic soy agar (TSA), 5\% bovine blood agar supplemented with vitamin $\mathrm{k}$, hemin and minadion, nutrient agar and mannitol salt agar (Carlton et al.,1993). 
Liquid media: Tryptic soy broth (TSB), 1\% bacto-peptone broth and semisolid agar tubes.

Reagents: Gram's stain, $\mathrm{H} 2 \mathrm{O} 2$, urea, nitrate and oxidase streps. Physiological saline and 3\% washed rabbit erythrocytes were used for dilution and hemagglutination test (Simon,1975).

\section{Bacterial isolation and identification:}

Under aseptic condition, loopfuls from affected beaks, tongues, livers and legs inoculated into media then incubated at $37^{\circ} \mathrm{C}$ anaerobically for 48 hours (Bennett and Duerden, 1985). The obtained colonies were identified by morphological, biochemical and hemagglutination test (Table 2). Colonies were kept on TSB containing 1\% agar for further investigations. (Domingo et al., 1992).

\section{Sensitivity test:}

In vitro antibiotic sensitivity testing of the isolated strains was performed against 13 antibacterial agents using disc diffusion technique (Quinn et al., 1994), (Table 3).

\section{Experimental infection:}

Bacterial inoculum isolated from chickens suffering from severe head and leg necrosis with high mortality was chosen for experimental infection. The inoculum was grown on $5 \%$ bovine blood agar supplemented with vitamin $\mathrm{k}$, hemin and minadion, incubated anaerobically at 37 ${ }^{\circ} \mathrm{C}$ for 48 hours then subcultured on fastidious anaerobic agar (FAA) media (Lab M. Ltd.,Bury, UK). One colony was picked up and inoculated in $5 \mathrm{ml}$ peptone water and incubated at $37{ }^{\circ} \mathrm{C}$ for 48 hours. Serial ten fold dilution was carried out using peptone water. Growth was judged by turbidity (Cruickshank et al., 1975). Each bird received 0.1 $\mathrm{ml}$ of $10^{9}$ dilution by oral rout and the same dose by scarification. 
A total of 12, one-week-old commercial broiler chickens were used for experimental infection. Two birds were examined bacteriologically to sure freedom of the described microorganism before artificial infection. The other chicks, each bird received $0.1 \mathrm{ml}$ of $10^{9}$ dilution orally and the same dose by scarification. Two birds from each group were necropsied on 5, 10, 20 and 30 days post infection (PI). Clinical signs and postmortem findings were recorded and the organism was re-isolated from the infected birds (Domingo et al., 1992).

\section{Histopathological examination:}

Samples from beaks and shanks of experimentally infected birds were fixed in $15 \%$ formalin, dehydrated in ethanol, cleared in xylene, embeded in paraffin, sectioned of $5 \mu \mathrm{m}$ thickness and stained with hematoxylin and eosin (H\&E) according to Bancroft and Cook (1993).

\section{RESULTS AND DISCUSSION}

The present study was a trial to isolate F. necrophorum from broiler chickens suffering from beak and shank necrosis. F. necrophorum has been isolated from 7-week-old broiler chickens 14 out of 111 (12.6\%) clinical cases collected from 9 flocks suffered from beak and leg necrosis. Mandibuler disease with beak necrosis and scab formation on the beak and legs were considered the reason of outbreak. The epidermis become dry and peeled off (Table 1).

Beak and shank necrosis occured in $56 \%$ of chickens suffered from erosions and necrosis of beak and legs, off food, depression, growth retardation and mortality ranged from 2-13\%. Similar findings were reported by Cheng et al., 1976 with incidence of $48 \%$ in female broiler breeders and about 10\% mortality. Examined chickens suffered from necrosis and ulcerations with hypertrophy of the upper or lower beak or sometimes both. The beak of the examined live birds showing varying 
degree of the lower mandible involvement and the beak appeared to be straight, with food particles adhering to both mandibles. Some chickens had blood coming from the nostrils. Early cases showed erosion of the epidermis. In severe cases, lower mandible was almost completely gone. Eating and drinking in advances cases appeared to be extremely difficult. The legs of the birds showed weakness, necrosis, depression and some birds had leg paralysis. Similar findings were reported by Barr, 1965 when described the condition of beak necrosis in a chicken flock considered basically to be a defect in the beak (curvature of the upper mandible) allowing impaction with food.

Isolation of the organism from the affected organs revealed anaerobic, Gram negative, filamentous bacteria. The prevalence of the organism was high in beaks $(12.6 \%)$, followed by liver $(9.9 \%)$ then by shanks (6.3\%). Cheng et al. (1976) reported that beak necrosis occurred in $48 \%$ of female broiler breeders and caused $10 \%$ mortality. However, Nakamura et al. (1997) reported the morbidity of beak necrosis was $10 \%$ and that of leg weakness was $3 \%$.

Depression, decreased body weight, lameness, leg weakness and necrosis of beak and shanks were observed in experimentally infected chickens.

The isolated strains were subjected to morphological, culture character, hemagglutination and biochemical identification. They were typed as Fusobacterium necrophorum (Table 2).

The In vitro antibiotic sensitivity test results revealed that the isolates were sensitive to amoxicillin, ampicillin, penicillin, oxytetracycline and nalidixic and resistant to sulphamethoxin, gentamycin and streptomycin (Table 3). Similar findings were observed by Ugenbuhi et al. (1986). 
Histopathological examination of masses from beaks and other parts of the head revealed hyperkeratosis in stratum cornium with fragmentation and keratolysis (Fig. 1). Hyperplastic prickle cell layer existed ballooning degeneration and rod-shaped microorganisms infiltrated in areas of epidermis and dermis suffered from coagulative necrosis (Fig. 2). The epithelium of the epidermis invaded the dermis and arranged in cylinder clusters (Fig. 3). The dermal layer was greatly thickened occionally hyperplasia of the fibrous tissue with concentrically arrangement or wheal like appearance in dermis and subcutis (Fig.4). Also bluish rod-shaped bacteria were scattered in the tissue blood vessels were occluded with inflammatory cells. Cheng et al., (1976) reported that the bacteria associated with beak necrosis appeared to be single morphological type invaded the keratinous material of the beak and occupied sockets in the beak tissue and the distribution of these bacteria within the tissue was consistent with invasion and digestion of the beak by a keratinolytic strain of bacteria. Similar findings were obtained by Nakamura et al. (1997) who reported that the lesions were liquifactive necrosis of epidermal cells and degenerated keratocytes with necrosis of the basal layer, congestion and hemorrhage were seen in severe lesions.

The epidermis of the shank at local areas affected with hyperkeratosis, hyperplastic changes and hydropic degeneration in prickle cell layer. At definite area sloughing of the epidermis occurred with coagulative necrosis of the underling tissue which was intangled with rod-shaped bacteria (Fig. 5). Considerable infiltration of degenerated granulocytes were detected in dermis and subcutis (Fig. 6). Nakamura et al., (1997) reported that no lesions could be found in the peripheral nerves, joints or muscles and there was no marked epidermal hyperplasia with intracytoplasmic inclusions in legs of chickens suffered from leg weakness. We could conclude that F. necrophorum is a severe pathogen invading the keratinous material of beak and shank causing necrosis, growth retardation and losses in chickens. Further studies concerning the pathogenesis of single and mixed infections are required. 
Prevalence Of Beak And Shank Necrosis In Cross-Bred Chickens.

Table (1): The incidence of F. necrophorum in some chicken flocks in Gharbea Province:

\begin{tabular}{|c|c|c|c|c|c|c|c|c|c|c|c|c|c|}
\hline \multicolumn{3}{|c|}{ Flocks } & \multicolumn{9}{|c|}{ Cases } & \multicolumn{2}{|c|}{ Locality } \\
\hline \multirow{2}{*}{ Locality } & \multirow{2}{*}{ No. } & \multirow{2}{*}{ Age/week } & \multirow{2}{*}{ No. } & \multicolumn{2}{|c|}{ Beak } & \multicolumn{2}{|c|}{ Liver } & \multicolumn{2}{|c|}{ Shank } & \multirow{2}{*}{$\begin{array}{c}\text { Total } \\
+ \text { ve }\end{array}$} & \multirow{2}{*}{$\%$} & \multirow{2}{*}{$+v e$} & \multirow{2}{*}{$\%$} \\
\hline & & & & $+v e$ & $\%$ & $+v e$ & $\%$ & $+v e$ & $\%$ & & & & \\
\hline Santa & 5000 & 5 & 5 & 0 & & 0 & & 0 & & 0 & & -ve & \\
\hline Birma & 5000 & 6 & 10 & 2 & & 2 & & 1 & & 2 & & $+\mathrm{ve}$ & \\
\hline Tanta & 4000 & 5 & 15 & 2 & & 1 & & 1 & & 2 & & $+\mathrm{ve}$ & \\
\hline Basiun & 5000 & 7 & 15 & 3 & & 2 & & 1 & & 3 & & $+\mathrm{ve}$ & \\
\hline Zifta & 10000 & 7 & 20 & 4 & & 3 & & 2 & & 4 & & $+\mathrm{ve}$ & \\
\hline Birma & 5000 & 5 & 6 & 0 & & 0 & & 0 & & 0 & & -ve & \\
\hline Qotor & 10000 & 6 & 20 & 3 & & 3 & & 2 & & 3 & & $+\mathrm{ve}$ & \\
\hline Basiun & 10000 & 7 & 10 & 0 & & 0 & & 0 & & 0 & & -ve & \\
\hline Qotor & 10000 & 6 & 10 & 0 & & 0 & & 0 & & 0 & & -ve & \\
\hline Total & & & 111 & 14 & 12.6 & 11 & 9.9 & 7 & 6.3 & 14 & 12.6 & 5 & 56 \\
\hline
\end{tabular}

Table (2): Morphological and biochemical identification of F. necrophorum isolated from chickens.

\begin{tabular}{|c|c|c|c|}
\hline \multirow{2}{*}{ Test } & \multicolumn{3}{|c|}{ Organs } \\
\hline & Beak & Liver & Shank \\
\hline Gram's stain & -ve & -ve & -ve \\
\hline Motility & $+\mathrm{ve}$ & $+\mathrm{ve}$ & $+\mathrm{ve}$ \\
\hline Haemagglutination & $+\mathrm{ve}$ & $+\mathrm{ve}$ & $+\mathrm{ve}$ \\
\hline Haemolysis & -ve & -ve & -ve \\
\hline Oxidase & $+\mathrm{ve}$ & $+\mathrm{ve}$ & $+\mathrm{ve}$ \\
\hline Catalase & $+\mathrm{ve}$ & $+\mathrm{ve}$ & $+\mathrm{ve}$ \\
\hline Urease & $-\mathrm{ve}$ & $-\mathrm{ve}$ & -ve \\
\hline Nitrate & -ve & $-\mathrm{ve}$ & -ve \\
\hline Pigment & $-\mathrm{ve}$ & $-\mathrm{ve}$ & -ve \\
\hline
\end{tabular}

Table (3): Antibiotic sensitivity test of F. necrophorum isolates to different antibacterial agents

\begin{tabular}{|c|c|c|c|c|}
\hline No. & Antibacterial agent & $\begin{array}{c}\text { Potency of disc } \\
(\mu \mathrm{g})\end{array}$ & $\begin{array}{l}\text { Standard sensitivity } \\
\text { zone }(\mathbf{m m})\end{array}$ & $\begin{array}{c}\text { Inhibition zone } \\
(\mathbf{m m})\end{array}$ \\
\hline 1 & Penicillin $(\mathrm{P})$ & 10 & $21>29$ & 25 \\
\hline 2 & Ampicillin (AML) & 30 & $17 \geq$ & 35 \\
\hline 3 & Amoxycillin (AMX) & 25 & $23>31$ & 32 \\
\hline 4 & Chloramphenicol (C) & 20 & $13>18$ & 15 \\
\hline 5 & Oxytetracycline (OT) & 30 & $13>16$ & 25 \\
\hline 6 & Trimethoprim (SXT) & 30 & - & 18 \\
\hline 7 & Enrofloxacin & 5 & $16>21$ & 18 \\
\hline 8 & Sulphamethoxin (SM) & 25 & - & - \\
\hline 9 & Nalidixic acid (NA) & 30 & $19 \geq$ & 29 \\
\hline 10 & Gentamycin (GM) & 30 & $17 \geq$ & 20 \\
\hline 11 & Norfloxacin ( NOR) & 10 & $20 \geq$ & 22 \\
\hline 12 & Ciprofloxacin (FLC) & 40 & $21 \geq$ & 24 \\
\hline 13 & Streptomycin $(\mathrm{S})$ & 10 & $15 \geq$ & - \\
\hline
\end{tabular}

Kafrelsheikh Vet. Med. J. Vol. 7 No. 1 (2009) 
Moshira A. El-Abasy et al.,

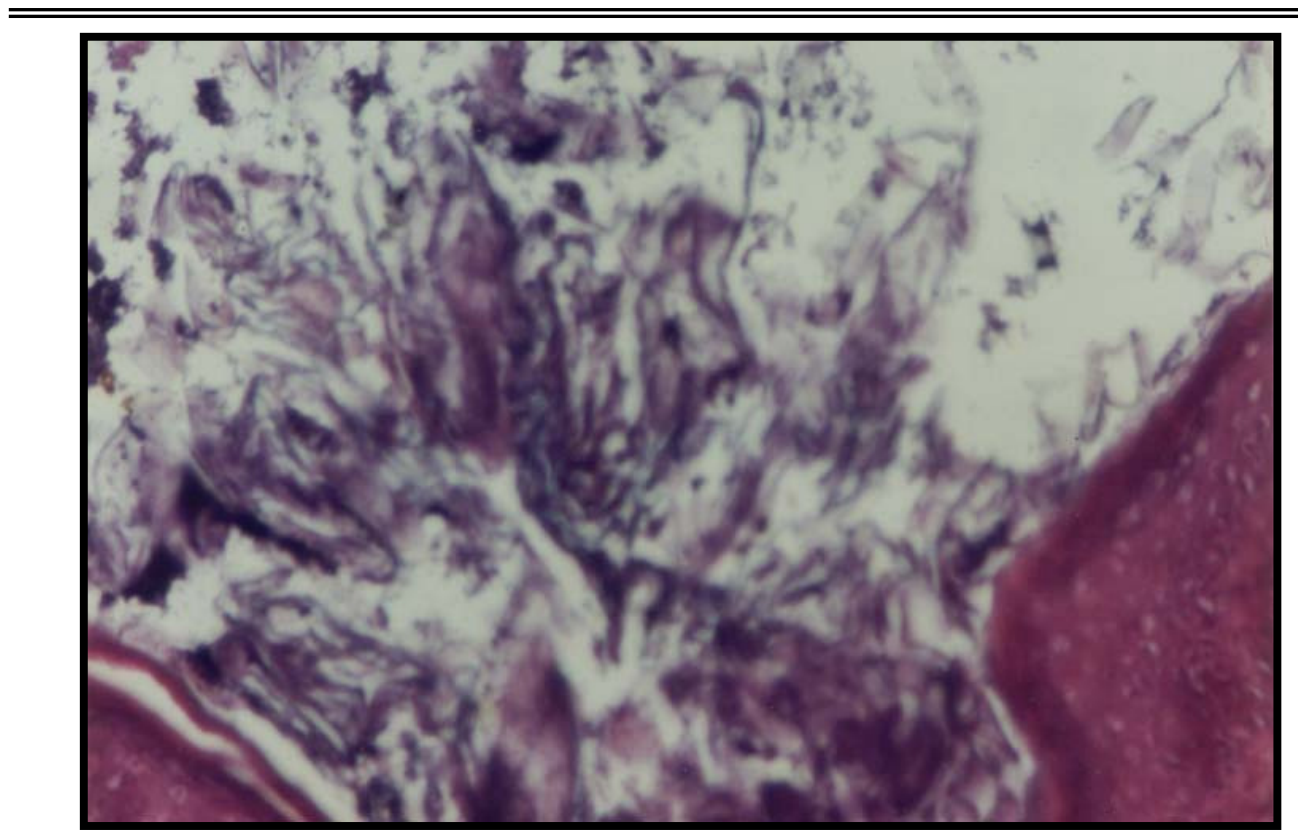

Fig. (1): Stratum cornium showed fragmentation and keratolysis (H\&E X250).

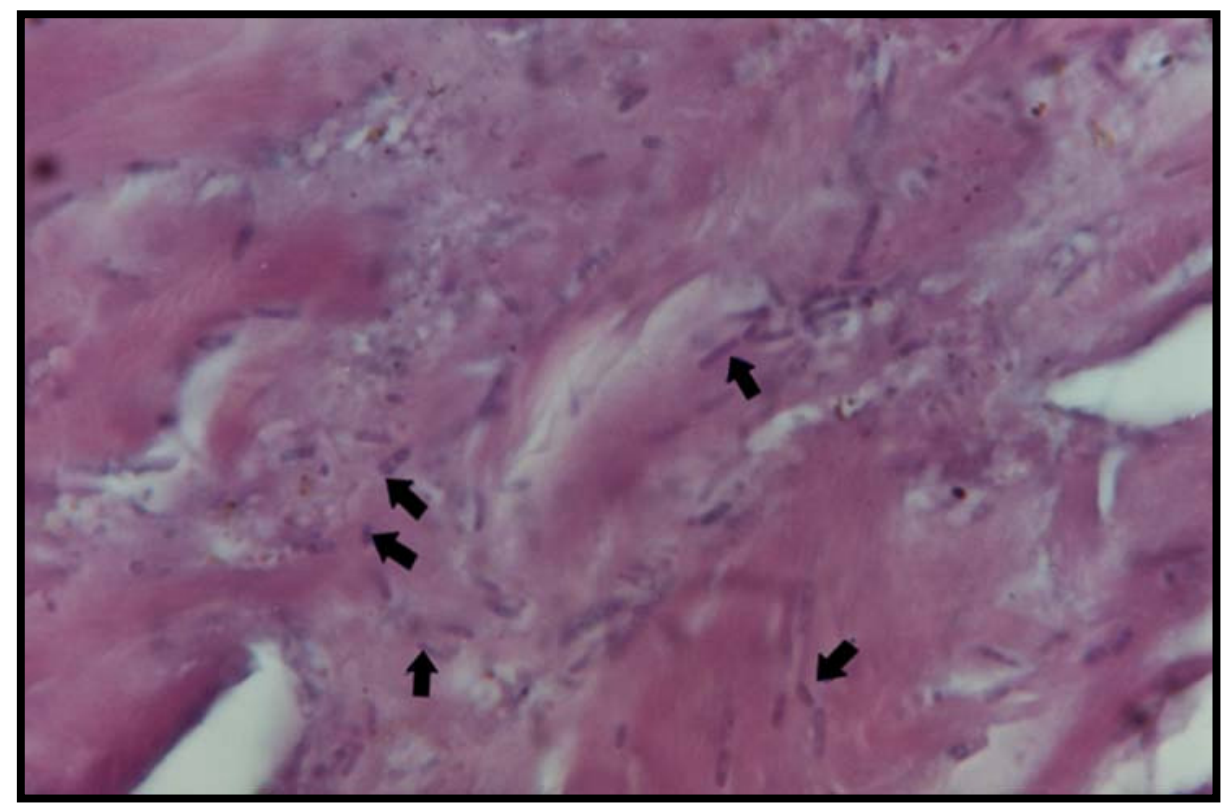

Fig (2): Rod-shaped bacteria in the dermis (H\&E X1000).

Kafrelsheikh Vet. Med. J. Vol. 7 No. 1 (2009) 


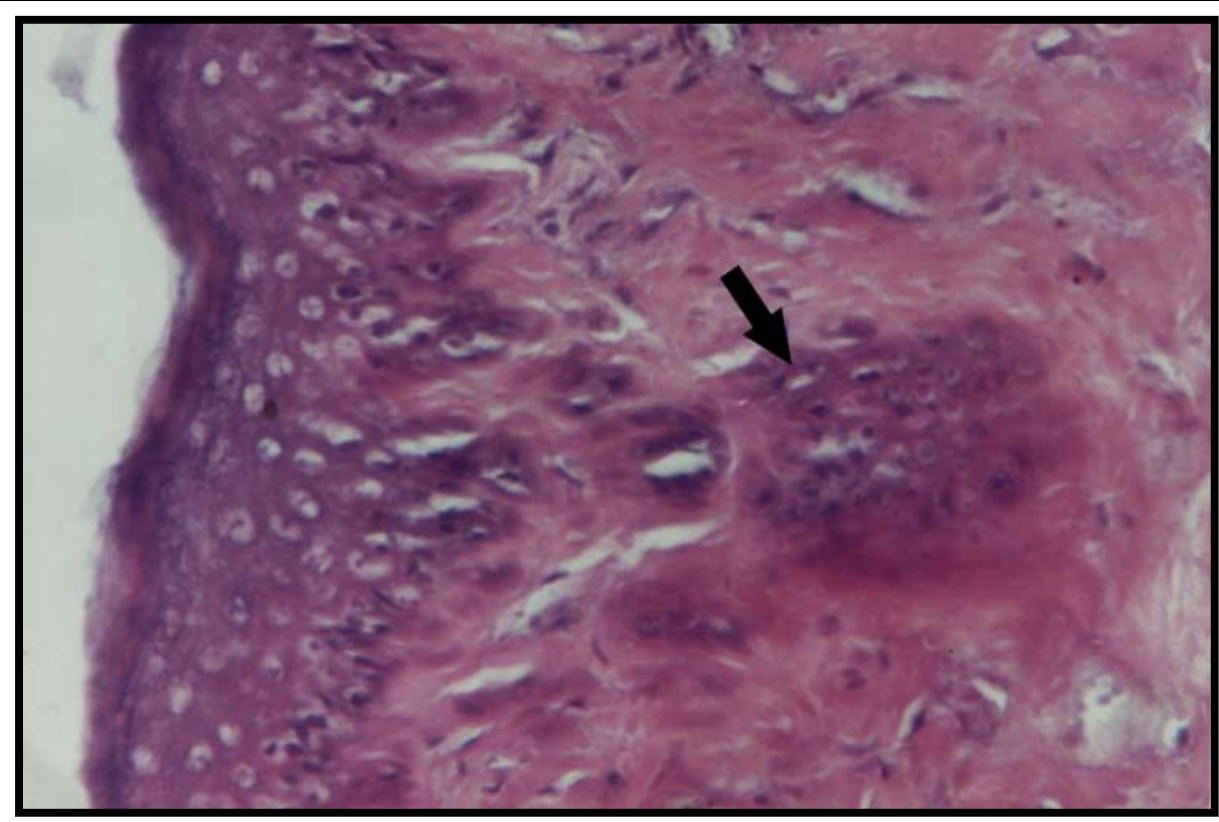

Fig (3): Epithelial cells of the epidermis invade dermal layer (H\&E X400).

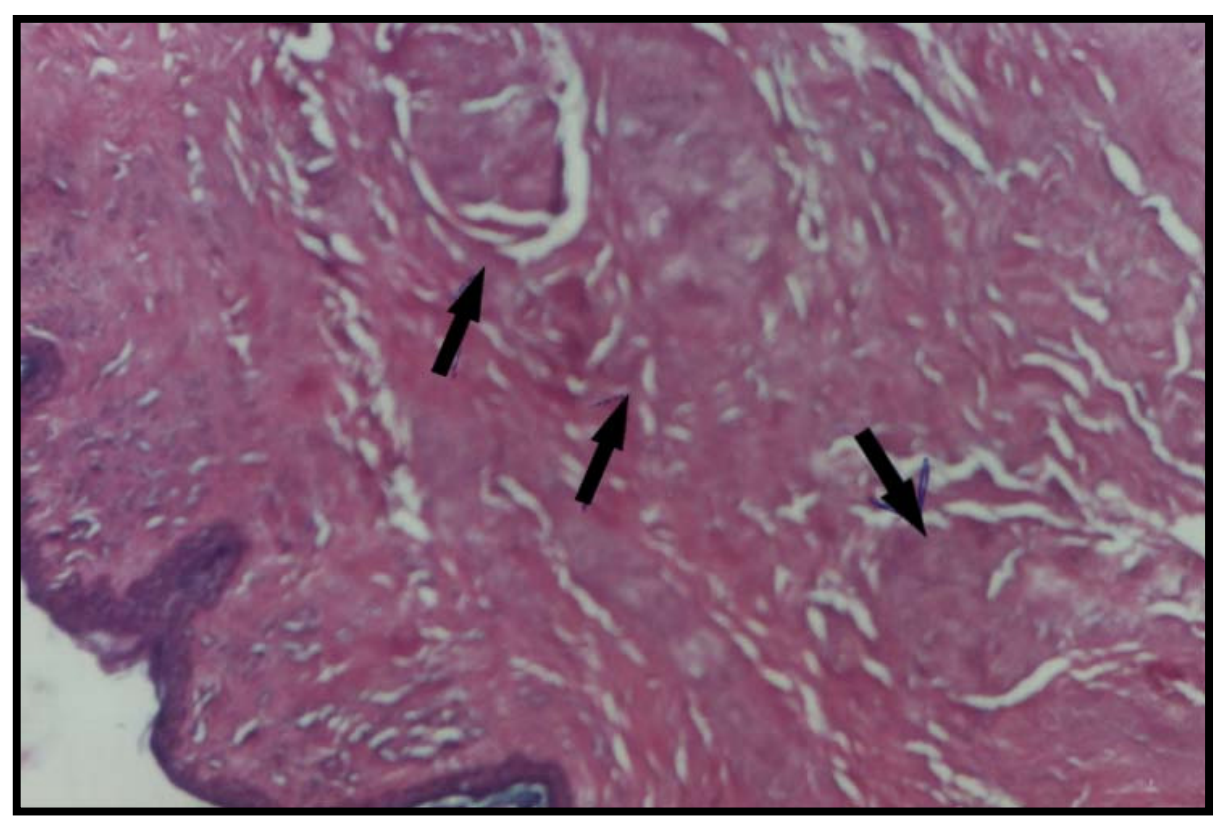

Fig (4): Hyperplastic fibrous tissue with concentrically arrangement in dermis (H\&E X100). 
Moshira A. El-Abasy et al.,

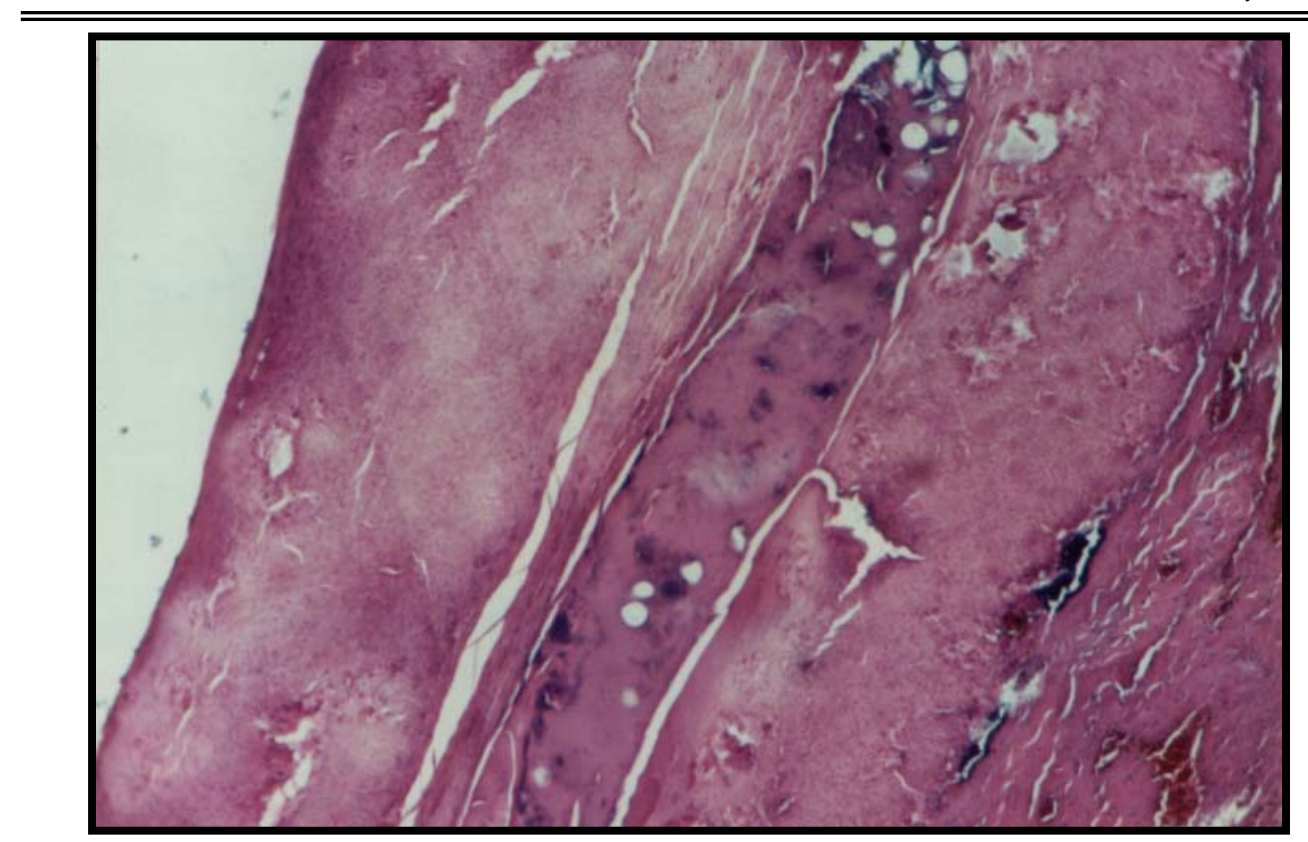

Fig (5): Sloughing of the epidermis with coagulative necrosis of underlying tissue (H\&E X250).

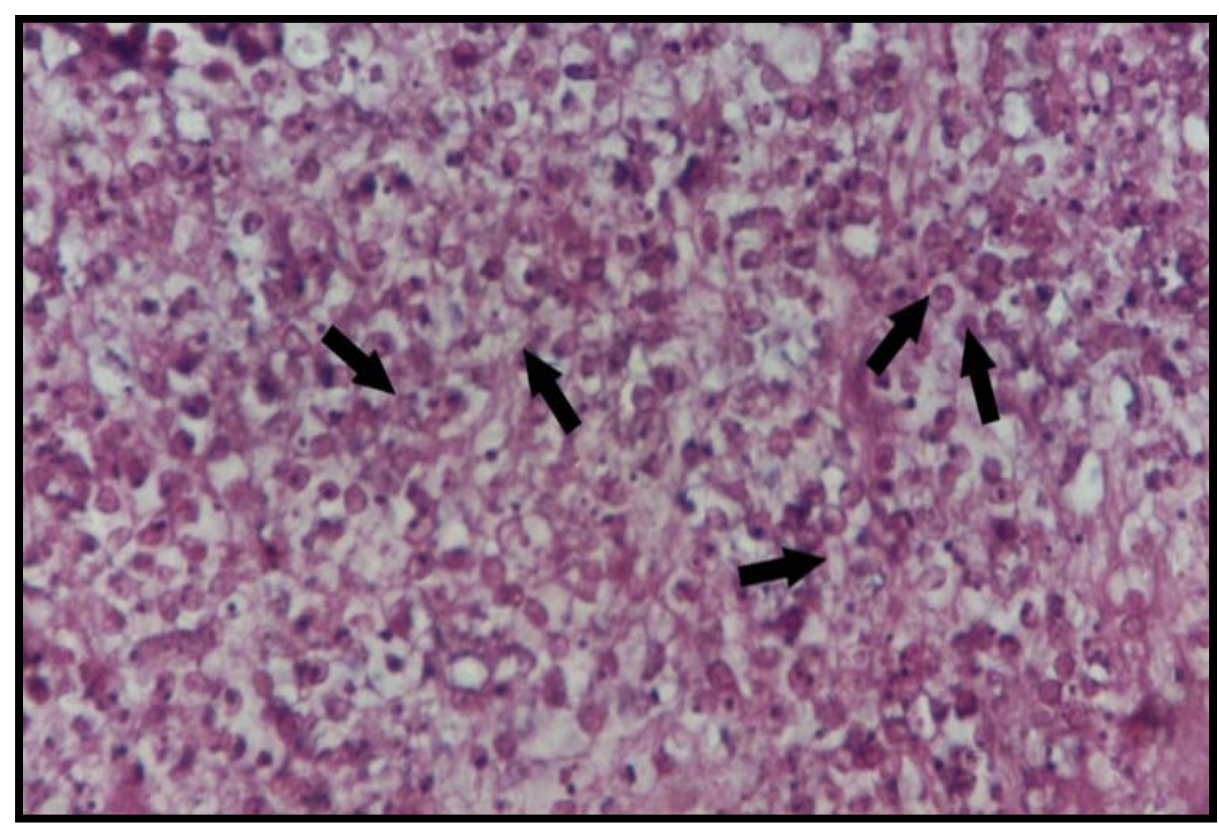

Fig (6): Dermis and subcutis showed degenerated granulocytes infiltration (H\&E X400).

Kafrelsheikh Vet. Med. J. Vol. 7 No. 1 (2009) 


\section{REFERENCES}

- Bancroft, J. D. and Cook, H. C. (1993): Manual of histopathological techniques $1^{\text {st }}$ ed. Chuchillivngstone, London and New York.

- Barr, M. (1965): Mentioned by Cheng in Bacteria associated with beak necrosis in broiler breeder hens. Vet. Rec. 77: 677.

- Bennett, K. W. and Duerden, B. I., (1985): Identification of Fusobacteria in a routine diagnostic laboratory. J. of Applied Microbiology. 59: 171-181.

- Carlton, B.; Schanning, S.; Santiagio, A.; Bickford, C.; Cordona, R.; Chin, G.; Cooper, R.; Droual, J.; Jrffer, C.; Meteyer, H.; Shivaprassa, D. and Walker, R. (1993): Preliminary characterization of pleomorphic Gram negative rod associated with avian respiratory disease. J. of Vet. Diagnostic investigation. 5: 47-51.

- Cheng, K.G.; Gardiner, E. E. and Costerton, G. W. (1976): Bacteria associated with beak necrosis in broiler breeder hens. Vet. Rec. 99: 503-505.

- Cruickshank, R. J.; Dugaid, P.; Marmion, B. P. and Swain, A. H. (1975): Medical microbiology $12^{\text {th }}$ ed., Living Stone L. T. D. Edinburgh, London, New York.

- Domingo, D. T.; Jacowood, M. W. and Brown, T.P.(1992): Filamintous forms of Bordetella avium: Culture condition and pathogenicity. Avian Dis. 36: 707-713. 
- Hungerford, T. G. (1969): Fungal infection of general diseases In: Diseases of poultry $4^{\text {th }}$ ed. Angus \& Robertson Ltd., Sydney, Austeralia pp. 357-377.

- Nakamura, K., Shirai, J., Imai, K., Hihara, H. and Tanimura, N.(1997): Outbreak of comb necrosis in layer breeder chickens. Avian Dis. 41: 252-256.

- Quinn, P. J., Carter, M. E., Marke, B. K. and Carter, G. R. (1994): Clinical Vet. Microbiology, Ed $4^{\text {th }}$.

- Simon, P. C. (1975): Asimple method for rapid identification of Sphaerophorus necrophorus isolates. Can. J. Comp. Med. 39: 349-353.

- Tripathy, D. N. Pox In: Diseases of poultry, $9^{\text {th }}$ ed. Calnec, B. W., Barnes, H. J. Beard, C. W., Reid, W. M. and Yoder, H. W. (1991): Lowa State University Press, Ames, Lowa pp. 583-596.

- Uginbuhi. G. L.; Cutter, D.; Cumpodonico, M. S.; Peace, J. and Simmons, D. G. (1986): Antimicrobial sensitivity test. Am. J. Vet. Res. 47: 619. 


\section{موت أنسجة المنقار والأرجل في الدجاج في محافظة الفربية}

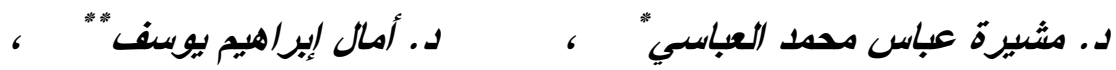
أ.د. عبد الجليل عبد الدقصود الجوهي"

" قسم أمراض الدو اجن - كلية الطب البيطرى - جامعة كفر الشيخ

$$
\text { " معهز بحوث صحة الحيوان- الدقى }
$$

استهدفت الدراسة التعرف على البكتيريا اللاهو ائية الخيطية سالبة الجرام الدسبية لتلف خلايا المنقار و السيقان في دجاج النسمين وذلك بفحص عدد 111 حالة من دجاج التسمين الهجين من 9 مز ارع في محافظة الغربية ـ وأوضحت نتائج العزل البكتيريولوجى من المنقار و الأرجل المصابة أن الميكروب اللاهوائى السالب لصبغة الجرام الذي يعمل على تلزن كرات الدم الحمراء أنه ميكروب الفيوزوباكتيريم نيكروفورم. وتم إجراء اختبار الحساسية للميكروب ضد 13 نوع من

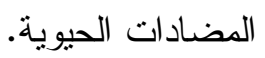

كانت الأعراض الإكلينيكية على الدجاج الذي تم فحصه هى تورم و نثوه وموت أنسجة المنقار وأطراف اللسان وأنسجة جلد السيقان. أسفرت ننائج الفحص الهيستوباثولوجى عن تضخم في الخلايا الكير اتينية وموت ونحلل هذه الخلايا فى أنسجة المنقار مع وجود تجمع للبكتيريا العصوية في هذه الخلايا المصابة مع وجود تضخم كير اتينى في خلايا جلد الساقين مصحوبا بتضخم وموت الأنسجة المبطنة المليئة بالبكتيريا

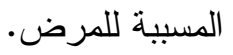

